\title{
The Students Teaching Quality in Teaching Experience Program at Vocational Secondary Schools
}

\author{
Istanto Wahyu Djatmiko, Samsul Hadi, Nurhening Yuniarti \\ Universitas Negeri Yogyakarta \\ Yogyakarta, Indonesia \\ istanto_wj@uny.ac.id
}

\begin{abstract}
Abstact-This paper is a part of study that aimed to determine the students' teaching activities quality that carried out in Teaching Experience Program (TEP) at Vocational Secondary School (VSS) as foundation of professional development for teacher candidates. Study conducted by the evaluation approach of professional development Guskey's model. Subjects were 50 students Study Program of Electrical and Mechatronics Engineering Education, Faculty of Engineering, State University Yogyakarta. Results of validity test by product moment and reliability test by Cronbach's alpha were known questionnaire coefficients of 0.30 to 0.70 and 0.90 respectively. Study results reveal less of students $(\mathbf{4 8 . 0 \%})$ had have students' teaching quality in category of "Very Good" and 50.0\% were "Good", which mean mostly of students $(98.0 \%)$ in excess of "Good" category in some activities of: starting lesson, setting up learning facilities, teaching-learning interaction, assessing learning process, and closing lesson.
\end{abstract}

Keywords: professional development for teacher candidates; teaching experience program

\section{INTRODUCTION}

Yogyakarta State University (YSU) is one of Teacher Education Institutions in Indonesia has main role to produce professional teacher candidates for vocational secondary schools. This condition has been reinforced by the Law Number 14 Year 2005 on Teachers and Lecturers [1] who confirmed teachers as profession that equal to other professions in Indonesia. It means YSU has a strategic strength in preparing prospective teachers to achieve national goals of education.

The curriculum of undergraduate for educational programs in YSU were developed by considering the characteristics of professional teacher candidates. Several educational and expertise courses were developed to equip students' competency required for prospective teachers. Teaching Experience Program (TEP) is one of the courses that prepared for students to get directly teaching experience in school. As described in [2], TEP was expected to provide a learning experience for students, especially in terms of teaching experience, increasing knowledge insight, training and improving competence, improving skills, enhancing self-directed, responsibility, and problem solving ability.
These indicators can be understood that TEP can be constructed as basis of teachers' professional development in the future.

As outlined in the Technical Guidelines of TEP 2016, TEP program conducted for two months at school or equal to 256 hours effectively at school. There are two main activities that implemented in TEP program in schools, namely: guided teaching activity and non-teaching activity. The guided teaching activity is a teaching activities with certain subjects in the classroom that conducted by students under supervised by counselor or teacher tutor. The nonteaching activity is implementation activities of TEP program which aim to improve classroom management, school management, or extra-curricular programs in schools. In implementation of TEP program, the time duration of the guided teaching activities is greater than the non-teaching activities time.

The students' teaching quality in TEP is one of aspects that can be influence in learning outcomes and also be used to measure the achievement level of TEP at schools. The improvements of TEP and its learning outcomes can be done through an evaluation study of students' teaching quality in TEP. Several procedures in the teaching-learning process can be selected during TEP implementation. Refer to [3] suggested several components can be conducted in the teaching and learning activities, i.e. setting goals, teaching materials, teaching and learning activities, methods, tools and resources, and evaluation. According to [4], there are five behaviors key in effective teaching, i.e. lesson clarity, instructional variety, teacher task orientation, engagement in the learning process, and student success rate. Those of two statements can be seen that there are two different arguments in arranging teaching process to achieve the desired learning objectives.

In Manual Book of Micro-teaching [5], there are six steps involved in the teaching process when conducting TEP, i.e. starting lesson, setting up learning facilities, teaching-learning interaction, assessing learning process, and closing lesson. Six of these components is used as the 
guidance in assessing teaching activities when managing TEP at schools.

On the other hand, because of the tasks of teacher as a profession, professional development is required to teachers or teacher candidates to improve their own competence. In general, the professional development refers to the development of pedagogical knowledge and ability to teach the material with the aim to increase student learning, and related to the development and promotion of career advancement in the future [6]. Another statement was stated by [7] that professional development is one aspect of learning and a way in with teachers or teacher candidates can understand the need to change, and that this involves continual learning from, whether formally or informally. These arguments can be understood that professional development is one aspect of learning for teachers or teachers' candidates to understand meaningfulness of changes. It means, professional development for teacher candidates who will conduct TEP at vocational secondary school is involved to enhance their knowledge, skills, and performance to be able to adapt to changes in science and technology. By professional development activities followed by teacher candidates are expected to have an impact on improving teaching learning quality in the classroom.

Above descriptions can be summarized that the relationship TEP to build professional development for teacher candidates at vocational secondary school necessary to be known carefully through research. This paper is a part of study was conducted to evaluate the implementation of TEP based on [8] of Guskey's model of professional development, where the objectives of this study was expected to obtain an overview of students' teaching quality during their conducting TEP at vocational secondary schools. Thus, results of this study can be used as feedback and to improve TEP in the future.

\section{METHOD}

This paper is one part of evaluation research of TEP at vocational secondary schools as basis of professional development for teacher candidates using the Guskey's evaluation model approach of [8], which have five stages, namely (1) participants' reactions, (2) participants' learning, (3) organization support and change, (4) participants' use of knowledge and skills, and (5) student learning outcomes. The study procedures can be shown as Figure 1.

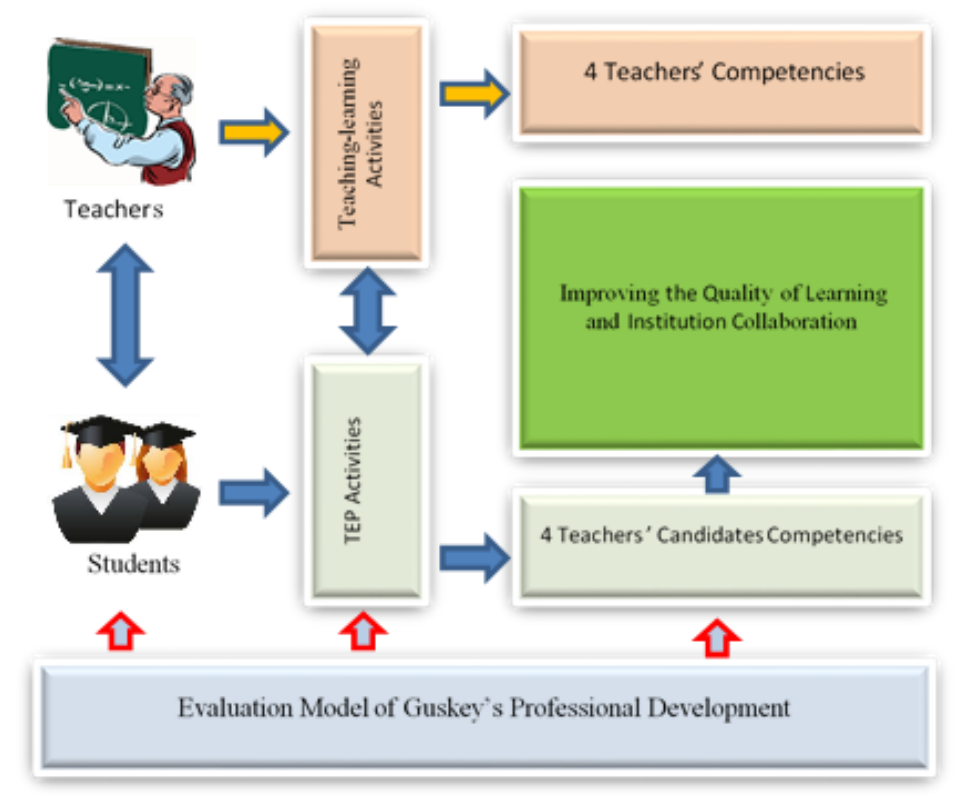

Figure 1 Study Procedures

Guskey's evaluation of professional development procedure on the implementation of the TEP program can be divided into five evaluating activities, i.e. (1) students' participation in TEP activities, (2) teaching quality in classes conducted by students' TEP, (3) collaboration quality among YSU-School (Vocational Secondary
School)-TEP's Students in managing TEP, (4) enhancement of new knowledge and skills by TEP's students during TEP at schools, and (5) impacts of TEP's activities to perform four competencies to teacher candidates.

This paper will be described the results of teaching quality in classes conducted by students' 
TEP at vocational secondary schools. The subjects of this study were 50 students of both Electrical Engineering Education and Mechatronics Engineering Education Study Programs, Faculty of Engineering Yogyakarta State University (YSU) that distributed at 12 Public and Private of vocational secondary schools in collaboration with YSU's TEP in 2016 in Yogyakarta Special Territory, Indonesia. Data was collected using the questionnaire consisted of 29 statements with four alternative answers, i.e. very good, good, fair, and poor. Data were categorized into four qualitative groups of data based on minimum score (Min), maximum score (Max), average score $(\mathrm{X})$, and standard deviation $(\mathrm{SD})$, i.e. $(\mathrm{X}+(1.5 \mathrm{SD}))$ to Max is very good, $\mathrm{X}$ to $(\mathrm{X}+(1.5 \mathrm{SD}))$ is good, $(\mathrm{X}-(1.5$ $\mathrm{SD}))$ to $\mathrm{X}$ is fair, and Min to $(\mathrm{X}-(1.5 \mathrm{SD}))$ is poor.
The validity and reliability of the questionnaire were tested using Pearson's Product Moment test and Cronbach's Alpha test. Results of those tests were obtained coefficient values respectively between 0.30 to 0.70 and 0.90 . Data were analyzed using descriptive statistics and presented in frequency distribution categories and graphics.

\section{RESULTS AND DISCUSSION}

There are five activities related to teaching quality was undertaken by students when conducting TEP at schools, namely: starting lesson, setting up learning facilities, teachinglearning interaction, assessing learning process, and closing lesson. Data of those of fifth aspects can be illustrated in Figure 2.

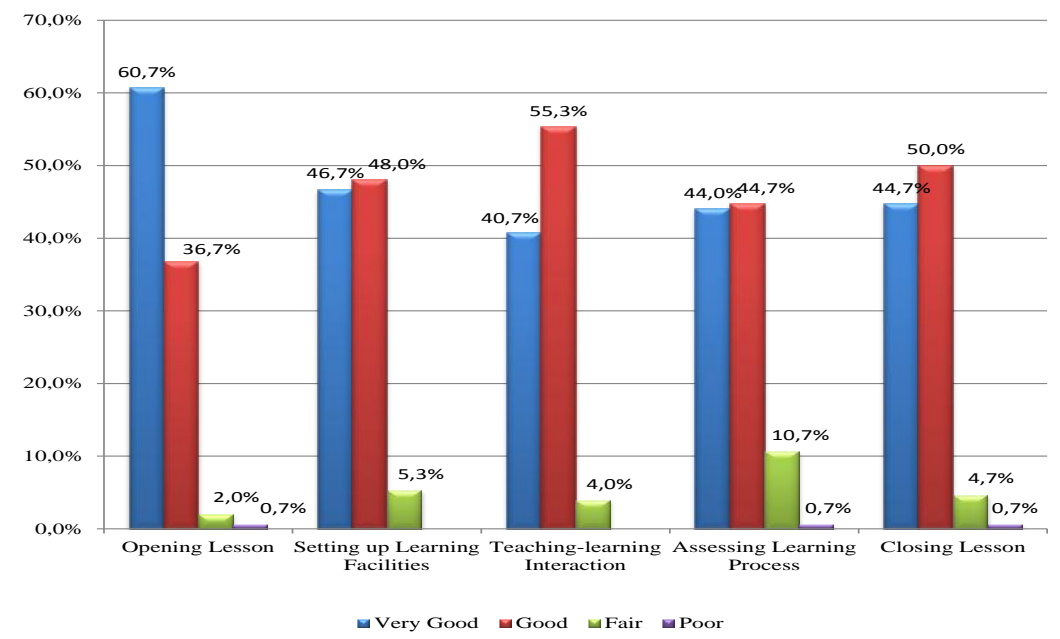

Figure 2. Teaching Activities Quality of Students' TEP

The teaching quality of TEP is the students' performance in teaching-learning process activities on certain subjects that were planned by them in the form of activities matrix. Starting learning is the first of the learning process that must be overcome by students' TEP teachers. Several activities in starting learning should be mastered by students in implementing TEP, including: understanding learners' characteristics, giving apperception, and delivering learning objectives.

Figure 2 can be shown the teaching activities quality of students' TEP is mostly of students $(60.7 \%)$ were included "Very Good" category and less of students $(36.7 \%)$ were included in "Good" category in the starting lesson activities in the classroom. Its means that mostly students $(97.4 \%)$ had been conducting the starting lesson at the beginning of teaching process in the classroom included in excess of "Good" category. These conditions were expected by [9] that starting lesson skills was an activity performed by teachers or teacher candidates in teaching activities in order to create preconditions so that students had have interest and attention during teaching-learning process. Therefore, starting lesson activities can able to ensure that students are ready to receive in learning. The TEP's students can able to prepare learning situations before opening lesson that the students were able to prepare themselves in learning process.

Preparation of learning facilities should be setup by TEP's students before conducting learning process in classroom. Those learning facilities were included lesson plan, tools and media learning, and teaching materials such as: modules, job sheets or lab sheets. The quality on setting up learning facilities when students conducted TEP can be described in Figure 2. Figure 2 can be explained 
less of students (46.7\%) were included in "Very Good" category and less of students $(48.0 \%)$ were included in "Good" category or to be otherwise mostly of students $(94.7 \%)$ had set up learning facilities in advance of conducting learning process were included in excess of "Good" category. Preparing instructional media, an example in learning process, according to [10] they can be used as an intermediate in learning process to enhance the effectiveness and efficiency in achieving learning objectives. This means usage of instructional media would greatly assist teachers in learning activities so that the message will be more easily understood by students.

Interaction quality between students and teacher during learning process will determine learning process quality in classroom. Some of activities should be prepared by students to improve interaction quality during learning process were included: able to master teaching material to be taught, able to manage the classroom effectively such as steps in teaching, communication in speaking and gesturing, and able to use methods and medias learning, questioning, and usage learning time effectively.

The quality of TEP's students and teacher interaction during learning process in the classroom can be shown in Figure 2. Figure 2 can be understood less of students $(40.7 \%)$ were considered in "Very Good" category and less of students $(55.3 \%)$ were considered in "Good" category or overall mostly students $(96.0 \%)$ can be stated that the students' interaction quality in learning process for TEP were in excess "Good". These circumstances as stated [3], classroom management was one of skills to create and to maintain more optimally learning conditions as well as educationally interaction process. This means if interactions between students and teacher activities can be implemented properly, of course, it will have positive impact on students' learning outcomes.

Assessing learning output is an activity must be done by the TEP's students during teaching and learning process in vocational secondary schools. These learning output assessment activities were included the conformity assessment techniques with the aims of learning, assessment procedures clarity, completeness of instruments, and assessment follow-up. Figure 2 can be explained the quality of TEP's student on learning assessment activities, where less of students $(40.0 \%)$ were of categorized as "Very Good" and less of students (44.7\%) were "Good" or on the whole it can be stated that the quality of TEP's students learning assessment activities of mostly students $(84.4 \%)$ were included in excess of "Good".

These conditions mean the quality of learning assessment can be used to determine the effectiveness of ongoing learning process and the achievement of learning objectives. As stated by [11], assessment of students' learning output was conducted to determine the effectiveness of students learning output and to determine whether the objectives that have been formulated can be achieved by students through learning. Therefore, the assessment of learning output can be used to assess students' achievement, to increase students' understanding, and as feedback to improve further lesson plan.

Closing lesson activity is the end of learning process of each learning activity in the classroom in order to TEP. These activities were at least able to conclude learning, able to assign tasks, and able to describe further lesson materials. Figure 2 can be known the quality of students' closing learning activities during TEP at vocational secondary schools, who less of students $(44.7 \%)$ were categorized as "Very Good" and less of students $(50.0 \%)$ were "Good" or it can be stated that the quality of students' closing lesson of mostly TEP's students $(94.7 \%)$ were included in excess of "Good". These results were presented by [11] that the closing lesson is one of learning process activities was undertaken by teacher to determine the achievement of learning objectives, students' understanding of the lesson has been studied, and closing learning activities. Thus, closing lesson skills were necessary for TEP's students to know the successfulness of students in reaching subject matter so that it means can able to measure the achievement of TEP's students in teaching-learning process.

Overall students' teaching quality in TEP at Vocational secondary schools can be concluded less of students $(48.0 \%)$ were included in "Very Good" category and less of students $(50.0 \%)$ were "Good". These mean mostly students $(98.0 \%)$ were in excess of "Good", which includes activities as follow: starting lesson, setting up learning facilities, teaching-learning interaction, assessing learning process, and closing lesson. 


\section{CONCLUSION}

Results of this paper can be concluded as follows: First, the starting lesson activities quality carried out mostly of students $(97.4 \%)$ at the beginning of the learning process in the classroom were included in excess of "Good" category, which include: understanding learners' characteristics, giving apperception, and delivering learning objectives.

Second, the quality of setting up learning facilities implemented mostly of students (94.7\%) to prepare before carrying out the learning process in the classroom were included in excess of "Good" category, which include: lesson plan, tools and media learning, and teaching materials such as: modules, job sheets or lab sheets.

Third, the quality of teaching-learning interaction between students and teacher in the TEP's learning process mostly of students $(96.0 \%)$ were included in excess of the of more than "Good" category, which include: able to master teaching material to be taught, able to manage the classroom effectively such as steps in teaching, communication in speaking and gesturing, and able to use methods and medias learning, questioning, and usage learning time effectively.

Fourth, the quality of assessing learning process mostly of students $(84.4 \%)$ were included in excess of "Good" category with some activities such as: conformity assessment techniques with the aims of learning, assessment procedures clarity, completeness of instruments, and assessment follow-up

Fifth, the quality of closing lesson in classroom mostly of students $(974.7 \%)$ were included in excess of "Good" category, which several activities at least able to conclude learning, able to assign tasks, and able to describe further lesson materials.

Overall the students' teaching quality in TEP in vocational secondary schools mostly of students $(98.0 \%)$ were included in excess of "Good" category in some activities, i.e. starting lesson, setting up learning facilities, teaching-learning interaction, assessing learning process, and closing lesson. Based on results of this study can be suggested a recommendation that improving quality of students' teaching during the TEP should be improved that concerned of their ability to carry out in learning assessment, preparing learning facilities, and closing learning activity. Improving this students' teaching quality can be done and delivered when they have taken micro teaching course that conducted before TEP.

\section{REFERENCES}

[1] Kemendikbud, Undang-undang Nomor 14 Tahun 2005 tentang Dosen dan guru (The Act of Teacher and Lecture Number 14 Year 2005). Jakarta: Kementerian Pendidikan dan Kebudayaan, 2005.

[2] UNY, Panduan PPL/ Magang III (Manual of teaching experience program). Yogyakarta: Universitas Negeri Yogyakarta, 2005.

[3] S.B. Djamarah and A. Zain, Strategi belajar mengajar (Teaching-learning Strategy). Jakarta: Rineka Cipta, 2006, p.41.

[4] G.D. Borich, 2007. Effective teaching methods: Research-based practice, Sixth Edition. New Jersey: Pearson Education, Inc, 2007, p.9.

[5] Tim Penyusun Panduan Pengajaran Mikro, Panduan pengajaran mikro (Manual book of micro-teaching). Yogyakarta: Universitas Negeri Yogyakarta, 2014.

[6] G. Trorey, Meeting the needs of the individual and the institution. Dalam Trorey, G.; and Cullingford, C. (Eds.). Professional development and institutional needs. Aldershot: Ashgate Publishing Limited, 2002, p.2.

[7] G. Nicholls, Professional development in higher education: New dimensions and directions. London: Kogan Page Limited, 2001, p.10.

[8] T. R. Guskey, Evaluating professional development. California: Corwin Press, Inc, 2000 ..

[9] U.S. Sa'ud. 2010. Pengembangan profesi guru (Developing Teacher's profession). Bandung: Alfabeta, 2010, p.56.

[10] U.S. Sa'ud.. Pengembangan profesi guru (Developing Teacher's profession). Bandung: Alfabeta, 2010., p.66.

[11] E. Mulyasa, Menjadi guru profesional menciptakan pembelajaran kreatif dan menyenangkan (Become professional teachers to create creative and fun learning). Bandung: PT Remaja Rosdakarya, 2009, p.84. 